\title{
Kunjungan Antenatal Care (ANC) Ditinjau dari Tingkat Pengetahuan Ibu Hamil Tentang Tanda Bahaya Kehamilan
}

\author{
Lina Oktavia \\ Program Studi DIII Kebidanan STIKES Al-Ma'arif Baturaja \\ Email: linaoktavia342@gmail.com
}

\section{ARTICLE INFO}

Article history:

Received 25 April 2018

Revised 17 May 2018

Accepted 19 May 2018

\section{Keyword:}

Knowledge

Pregnant

Signs of Danger in Pregnancy

ANC Visit

DOI:http://dx.doi.org/10.30604/jika.v3i1.95

\begin{abstract}
A B S T R A C T
Complications of pregnancy is one cause of still high maternal mortality (MMR) in Indonesia, namely bleeding as much as $28 \%$ and pregnancy poisoning (eklampsi) as much as $24 \%$. The signs of danger in pregnancy is a sign of a serious problem in pregnant women or the fetus they contain. Based on research, it has been recognized today that every pregnancy can have potential and bring risks to the mother. The purpose of this research is to know the relationship of pregnant mother knowledge, pregnancy alarm, and visit of ANC. This study uses crossectional method with the number of respondents as much as 71 pregnant women. Statistical analysis using chi square to determine the relationship between independent with dependent variables on $95 \%$ confidence level. The results showed that there was a correlation between pregnant mother knowledge about pregnancy alert with visit of ANC at Desi Fitriani Clinic of Baturaja Regency of Ogan Komering Ulu with $p$ value 0,001. The higher the level of knowledge of pregnant women about antenatal care will improve compliance in antenatal care visits.
\end{abstract}

(c) 2018, Jurnal Aisyah: Jurnal Ilmu Kesehatan.

All rights reserved.

\section{PENDAHULUAN}

Angka Kematian Ibu (AKI) menurut target Millenium Development Goals (MDG's) tahun 2015 yaitu 102/100.000 kelahiran hidup, untuk itu diperlukan upaya yang maksimal dalam pencapaian target tersebut. Menurut hasil Survei Demografi Kesehatan Indonesia (SDKI) tahun 2012, AKI di Indonesia masih berada pada angka 359/100.000 kelahiran hidup. Kejadian kematian Ibu bersalin sebesar 49,5\%, hamil $26,0 \%$, nifas $24 \%$. Komplikasi kehamilan merupakan salah satu penyebab masih tingginya angka kematian ibu (AKI) di Indonesia sampai saat ini, yaitu perdarahan sebanyak 28\% dan keracunan kehamilan (eklampsi) sebanyak 24\%. Tanda-tanda bahaya pada kehamilan merupakan suatu pertanda telah terjadinya masalah yang serius pada ibu hamil atau janin yang dikandungnya. Berdasarkan penelitian, telah diakui saat ini bahwa setiap kehamilan dapat memiliki potensi dan membawa resiko bagi ibu (Sembiring R. 2010). 
Secara tidak langsung kematian ibu dapat dipengaruhi oleh keterlambatan mengenali tanda bahaya dan membuat keputusan untuk segera mencari pertolongan, keterlambatan mencapai fasilitas kesehatan dan terlambat mendapat pertolongan pelayanan kesehatan. Oleh karenanya deteksi dini oleh tenaga kesehatan dan masyarakat tentang adanya faktor risiko dan komplikasi, serta penanganan yang adekuat sedini mungkin, merupakan kunci keberhasilan dalam penurunan angka kematian ibu dan bayi yang dilahirkannya (Sumarni, Rahma, Ikhsan M. 2014).

Antenatal Care (ANC) sebagai salah satu upaya penapisan awal dari faktor resiko kehamilan. Menurut Organisasi Kesehatan Dunia (WHO) antenatal care selama kehamilan untuk mendeteksi dini terjadinya resiko tinggi terhadap kehamilan dan persalinan juga dapat menurunkan angka kematian ibu dan memantau keadaan janin. Idealnya bila tiap wanita hamil mau memeriksakan kehamilannya, bertujuan untuk mendeteksi kelainan-kelainan yang mungkin ada atau akan timbul pada kehamilan tersebut lekas diketahui, dan segera dapat diatasi sebelum berpengaruh tidak baik terhadap kehamilan tersebut dengan melakukan pemeriksaan antenatal care (Wiknjosastro. 2010).

Deteksi saat pemeriksaan kehamilan sangat membantu persiapan pengendalian resiko. Apalagi ibu hamil yang tidak melakukan pemeriksaan kehamilan, maka tidak akan diketahui apakah kehamilannya berjalan dengan baik atau mengalami keadaan resiko tinggi dan komplikasi obstetri yang dapat membahayakan kehidupan ibu dan janinnya. Dan dapat menyebabkan morbiditas dan mortalitas yang tinggi (Damayanti dan Winarsih, 2015).

Seorang ibu hamil kemungkinan akan mengalami penyimpangan kehamilannya, komplikasi yang dapat dialami ibu hamil dibagi sesuai masa kehamilannya. Tanda bahaya kehamilan yaitu sakit kepala yang hebat, penglihatan kabur, bengkak di wajah dan jari- jari tangan, keluar caian pervaginam, gerakan janin tidak terasa dan nyeri perut yang hebat. Perdarahan pada trimester ketiga antara lain plasenta previa (pembukaan ari-ari yang menutupi jalan lahir, perdarahan, solusio plasenta, perdarahan dari pecahnya sinus marginalis serta perdarahan dari pecahnya vasa previa yang dapat membahayakan ibu maupun janin (Manuaba, IGB. 2010).

Peran bidan dalam memberikan Informasi pada ibu hamil yaitu bidan mengajak keluarga untuk aktif dalam memantau kemungkinan gejala-gejala pre eklampsia dan informasi hasil pemeriksaan kesejahteraan janin dalam kandungan. Informasi tersebut akan mengurangi beberapa kekhawatiran yang dirasakan ibu dan keluarga. Informasi yang diperoleh ibu akan memberikan pengaruh jangka pendek (immediate impact) sehingga menghasilkan perubahan atau peningkatan pengetahuan bagi ibu hamil (Lestari, D. L. 2014).

Studi pendahuluan yang dilakukan di Klinik Bidan Desi Fitriani Baturaja terhadap 10 ibu hamil tentang tanda bahaya kehamilan didapatkan sebanyak 7 ibu mempunyai pengetahuan cukup tentang tanda bahaya kehamilan dan 3 ibu hamil mempunyai pengetahuan kurang tentang tanda bahaya kehamilan.

Berdasarkan data serta fenomena diatas, maka penulis melakukan penelitian tentang hubungan tingkat pengetahuan ibu hamil tentang tanda bahaya kehamilan dengan kunjungan ANC.

\section{METODE}

Metode penelitian menggunakan metode survey analitik. Desain penelitian yang digunakan adalah desain penelitian Crossectional dengan, dimana variabel independen dan variabel dependen diobservasi sekaligus pada saat yang sama. Dalam penelitian ini yang dimaksud dengan 
variabel independen adalah pengetahuan ibu tentang tanda bahaya kehamilan, sedangkan yang dimaksud dengan variabel dependen adalah kunjungan ANC. Populasi penelitian adalah seluruh ibu hamil yang melakukan kunjungan pemeriksaan kehamilan di bidan Desi Fitriani. Sampel diambil total populasi periode bulan Januari - April 2017 yang berjumlah 71 orang. Lokasi penelitian di Klinik Bidan Desi Fitriani Baturaja Kabupaten Ogan Komering Ulu.

Instrumen yang digunakan studi dokumentasi dan menggunakan checklist. Analisa yang digunakan menggunakan analisa univariat yaitu dilakukan untuk menjelaskan karakteristik masing-masing variabel yang diteliti dengan menggunakan distribusi frekuensi dalam ukuran persentase dan bivariat yaitu Untuk menilai hubungan antara variabel independen dengan dependen yang merupakan kategori maka uji statistik yang digunakan adalah uji chi square, pada tingkat kepercayaan 95\%, dan hubungan dikatakan bermakna apabila $\mathrm{p}$ value $\leq 0.05$ dan tidak ada hubungan yang bermakna jika $p$ value > 0.05 (Hastono, Susanto, 2010).

\section{HASIL DAN PEMBAHASAN}

Berdasarkan tabel 1 diketahui bahwa dari 71 responden dengan kunjungan ANC yang tidak sesuai standar sebanyak 47 responden $(66,2 \%)$ dan sesuai standar sebanyak 24 responden $33,8 \%$.

Tabel 1. Distribusi Frekuensi berdasarkan Kunjungan Antenatal Care (ANC)

\begin{tabular}{|c|c|c|c|}
\hline No & Kunjungan ANC & Frekuensi & Prosentase $(\%)$ \\
\hline 1 & Tidak Sesuai & 47 & 66,2 \\
\hline 2 & Sesuai & 24 & 33,8 \\
\hline & Jumlah & 71 & 100 \\
\hline
\end{tabular}

Tabel 2. Distribusi Frekuensi berdasarkan Pengetahuan

\begin{tabular}{cllcc}
\hline No & & Pengetahuan & Frekuensi & Prosentase (\%) \\
\hline 1 & Baik & & 35 & 49,3 \\
2 & Cukup & & 26 & 36,6 \\
3 & Kurang & & 10 & 14,1 \\
\hline & & Jumlah & $\mathbf{7 1}$ & $\mathbf{1 0 0}$ \\
\hline
\end{tabular}

Berdasarkan tabel 2 diketahui bahwa dari 71 responden dengan pengetahuan baik sebanyak 35 responden (49,3\%), pengetahuan cukup sebanyak 26 responden $(36,6)$ dan pengetahuan kurang sebanyak 10 responden $(14,1 \%)$.

Pengetahuan dikelompokkan menjadi 2 kategori yaitu Tinggi dan Rendah. Dari total 71 responden terdapat 35 responden yang berpengetahuan baik dengan kunjungan ANC tidak sesuai standar sebanyak 29 responden $(82,9 \%)$ dan dengan kunjungan ANC sesuai standar sebanyak 6 responden $(17,1 \%)$. Dari 26 responden yang berpengetahuan cukup dengan kunjungan ANC tidak sesuai standar sebanyak 16 responden $(61,5 \%)$ dan dengan kunjungan ANC sesuai standar sebanyak 10 responden $(38,5 \%)$. Dari 10 responden yang berpengetahuan kurang dengan kunjungan ANC tidak sesuai standar sebanyak 2 responden $(20,0 \%)$ dan dengan kunjungan ANC sesuai standar sebanyak 8 responden $(80,0 \%)$. 
Dari hasil uji Chi Square didapatkan nilai $p$ value 0,001 artinya ada hubungan yang bermakna antara pengetahuan ibu dengan kunjungan ANC. Maka hipotesis yang menyatakan ada hubungan antara pengetahuan ibu dengan kunjungan ANC di Klinik Bidan Desi Fitriani Baturaja Kabupaten Ogan Komering Ulu terbukti

Hasil penelitian ini sama dengan hasil Hasil penelitian Erni dan Winarsih (2015) di RSUD Pandan Arang Boyolali terdapat hubungan tingkat pengetahuan ibu hamil tentang resiko tinggi kehamilan dengan kepatuhan kunjungan antenatal care pada ibu hamil.

Hasil penelitian ini juga di dukung oleh hasil penelitian Lestari (2014) di BPS Sri Indraswati Boyolali menunjukan ada hubungan pengetahuan ibu hamil tentang tanda bahaya kehamilan dengan kunjungan pemeriksaan Kehamilan dengan $p$ value 0,002 .

Tingkat pengetahuan responden tentang antenatal care diperoleh dari pengalaman tentang kehamilan, tingkat pendidikan, lingkungan, dan sebagainya. Pengalaman tentang kehamilan dapat diperoleh dari kehamilan yang dialami responden sendiri atau mendapat informasi dari pengalaman orang lain. Pengalaman seseorang ibu hamil tentang keberhasilan atau ketidakberhasilan tentang pengobatan terhadap suatu penyakit berpengaruh terhadap tingkat kepatuhan mereka terhadap nasehat tenaga kesehatan.

\section{KESIMPULAN DAN SARAN}

Ada hubungan antara pengetahuan ibu hamil tentang tanda bahaya kehamilan dengan kunjungan ANC di Klinik Bidan Desi Fitriani Baturaja Kabupaten Ogan Komering Ulu 2017 dengan $p$ value 0,001. Dari hasil penelitian dapat disimpulkan bahwa semakin baik pengetahuan ibu hamil tentang tanda bahaya kehamilan, persalinan dan nifas maka ibu hamil akan semakin mau memeriksakan kahamilannya secara teratur kepada petugas kesehatan selama periode kehamilannya. Semakin baik tingkat pemahaman ibu hamil tentang antenatal care tentunya semakin baik pula tingkat kepatuhannya dalam antenatal care.

Penelitian ini masih memiliki kekurangan karena masih banyaknya factor-faktor lain yang dapat menjadi variable independent dalam mempengaruhi kunjungan ANC. Hasil yang diperoleh dari penelitian ini dapat mendukung hasil-hasil penelitian sejenis sebelumnya. Selain itu hasil penelitian ini dapat dijadikan pijakan untuk melakukan penelitian lebih lanjut dengan subyek dan obyek penelitian yang lebih luas.

\section{DAFTAR PUSTAKA}

Damayanti, E., Winarsih. (2015). Hubungan Tingkat Pengetahuan Ibu Hamil tentang Resiko Tinggi Kehamilan dengan Kepatuhan Kunjungan Antenatal Care di RSUD Pandan Arang Boyolali. Surakarta: Universitas Muhammadiyah Surakarta.

https://publikasiilmiah.ums.ac.id/ha ndle/11617/3725.

Hastono, Susanto. (2010). Statistik Kesehatan. Jakarta: Rineka Cipta.

Lestari, D. L. (2014). Tingkat Pengetahuan Ibu Hamil tentang Tanda Bahaya Kehamilan Trisemester III di BPS Sri Indraswati Boyolali tahun 2014. digilib.stikeskusumahusada.ac.id/fil es/disk1/15/01-gdl-diyanlilis-730-1diyanli-3.pdf.

Manuaba, IGB. (2010). Ilmu Kebidanan, Penyakit Kandungan dan KB. Jakarta: EGC. 
Sembiring, R. (2010). Hubungan Anemia

Dalam Kehamilan Dengan Kejadian

Perdarahan Post Partum Di RSUP

H. Adam Malik Medan. Jurnal D-III

Kebidanan Mutiara Indonesia Vol.

2, No. 4, Desember 2010.

Sumarni, Rahma, Ikhsan M. (2014).

Hubungan pengetahuan dan Sikap

Ibu Hamil tentang Tanda Bahaya

Kehamilan, Persalinan dan Nifas

trehadap Perilaku ANC Puskesmas

Latambaga Kabupaten Kolaka.

http://repository.unhas.ac.id/handle/

123456789/11094

Wiknjosastro. (2010). Buku Panduan

Praktis Pelayanan Kesehatan

Maternal dan Neonatal, Edisi 1.

Cet. 12. Jakarta: Bina Pustaka. 
J urnal Aisyah: J urnal Ilmu Kesehatan, 3(1), J uni 2018, - 100

\section{Lina Oktavia}

